DOI: https://doi.org/10.24113/ijellh.v8i1.10406

\title{
Patriarchal Oppression in Pearl S Buck's novel The Good Earth.
}

Ms. Monica Sherly. H

Ph.D Scholar

Department of English

Nirmala College for Women

Coimbatore, Tamil Nadu, India

sherly.joe17@gmail.com.

Dr. Aseda Fatima.R

Assistant Professor and Head

Research Department of English

Nirmala College for Women

Coimbatore, Tamil Nadu, India

asedadavy@gmail.com

Abstract

The story of American literature begins in the early 1600's, long before there were any

"Americans". American literature blossomed with the skillful and brilliant writer during 1900s.

Pearl S Buck was born to the family of Presbyterian missionary in 1892 in West Virginia. Being a successful writer in nineteenth century, she published various novels and she was the first female laureate in America and fourth woman writer to receive Nobel Prize in Literature. 
DOI: https://doi.org/10.24113/ijellh.v8i1.10406

Oppression is an element that is common in patriarchal society where the women are always subjugated by the men in the family. This paper is to depict the men's oppression in the novel through the character Wang Lang and how the female character O-Lan is surviving from all the struggles that she faces from her own family members.

Literature always anticipates life. It does not copy it, but moulds it to its purpose.

Literature is the reflection of mind. It is the great creative and universal means of communicating to the humankind. This creativity shows the difference between the writers and the people who simply write their views, ideas and thoughts.

American literature began with the discovery of America. American literature begins with the orally transmitted myths, legends, tales and lyrics of Indian cultures. Native American oral literature is quite diverse. The story of American literature begins in the early 1600's, long before there were any "Americans". The earliest writers were Englishmen describing the English exploration and colonization of the New World.

Pearl Sydenstricker Buck was born to the family of Presbyterian missionary in 1857. Due to their missionary, Buck was taken to China in her early 1900's and she was brought up there. Her early education was in Shangai University and later she moved to America to do her masters in philosophy. Pearl S Buck was awarded the Nobel Prize in literature in 1932. She received Pulitzer Prize for her novel The Good Earth. Buck used the norms and rituals of traditional Chinese society in most of her works.

In the beginning of the novel, Wang Lang is the son of a poor farmer who is very old and sick. Wang Lang is the main male character in this novel who searches the bride for the sake of taking care of his father and to help in doing the household chores. The novel begins with the marriage of Wang Lang and O-Lan who was a slave working in Hwang family. His marriage 
DOI: https://doi.org/10.24113/ijellh.v8i1.10406

was not based on love because both the bride and groom had never met before. It was purely a match making marriage arranged by Wang Lang's father as he wanted a slave girl to take care of the family.

After the marriage, Wang Lang transfers all his household chores to his wife O-Lan. He says, "Take to my father first a bowl of hot water for his lungs" (13). Wang Lang wholly delivers that henceforth all his duties will be taken care by his wife O-Lan. All the men and the society have a notion that after the marriage that woman will get the position after the men in the family where they are married to. Even this is applicable for O-lan as she has to put her old, sick fatherin-law in the first position. Women in the family should always have the priority towards the old and sick persons living in the family.

Serving the family members, cleaning the house, cooking, taking care of the children are called as the domestic matters as the women are supposed to do after the marriage where the men in the family will sit and enjoy the service rendered by the women. Patriarchal oppression in OLan's life is Wang Lang's family was expecting a new born male-baby.

And then looking at the child again, this burst forth from him suddenly as though he had just thought of it. "We shall have to buy a good basketful of eggs and dye them all red for the village. Thus will everyone know I have a son" (291)

The above statement shows a clear view that Wang Lang is expecting a baby boy from whom the new generation is created. Thus the male character in the novel proves how he respects men than women even if it is still a new born baby. Wang Lang wanted to do his ritual to announce the village that he has got a boy in his family. He thinks that having a boy is a sign 
DOI: $\underline{\text { https://doi.org/10.24113/ijellh.v8i1.10406 }}$

of good luck as the son is depicting the good future connected with the new generation of his family.

O-Lan was a slave girl when she marries Wang Lang. Wang Lang did not tell to any of his villagers that his wife is a slave. He feels ashamed to tell about his wife to the villagers. When one of the villager visits Wang Lang's house, she asked,

"What is this slave woman doing in your house" .

Then O-lan waited for her husband's answer, but he did not answer, for he did not know what to say. When he did not speak, the hot, scanty tears welled slowly into her eyes, and she winked them to hold back the tears and at last she took the corner of her blue apron and wiped her eyes and said at last,

"It is a bitter thing in my house, and I have no mother's house to go back to anywhere" (201-202)

The above mentioned quotation gives a clear view that how O-Lan has been treated by her own family members and more importantly by her husband. The subjugation that O-Lan faces in her family is that she was just treated like the slave who was brought to Wang Lang's family under the name of marriage. She was not given importance as neither the wife nor as a human being. 
DOI: https://doi.org/10.24113/ijellh.v8i1.10406

Works Cited

Buck,Pearl.S. The Good Earth: A Novel, 1931. Print.

Gray,Richard A Brief History of American Literature : Wiley Blackwell Publication, 1985. Print. https://unwomen.org/en/digital-library/publications/2011/10 